\title{
PLANOS OU NÍVEIS DO MOVIMENTO UNIVERSAL. POR UM MATERIALISMO HISTÒRICO E GEOGRÁICO
}

\author{
Pedro Geiger \\ Professor visitante IGEOG/ UERJ \\ pedro.geiger@gmail.com
}

\begin{abstract}
Resumo
O artigo aborda a posição histórica da Geografia, em comparação a de ciências, no contexto do progresso tecnológico e da instalação do capitalismo; Muito antiga, a Geografia despontou como disciplina descritiva e narrativa da superfície terrestre e da diversidade de seus entes geográficos, produzidos pela natureza, ou socialmente construídos. As formulações teóricas sobre os movimentos do mundo real, inclusive os dos entes geográficos, passaram a se desenvolver durante a modernidade, providas pelo aparecimento de novas ciências. Estas, também oferecendo suporte à produção e à acumulação capitalista foram assumindo hierarquia maior. Uma série de acontecimentos convergiu para que na contemporaneidade mais recente, a Geografia, como a História reafirmassem a sua importância, como fontes de saber científico e filosófico. Mencionase, a difusão do materialismo histórico, o crescimento político da questão social, além da globalização e dos problemas ambientais. Todos estes movimentos, os da natureza e os sociais, são desdobramentos de um movimento único, iniciado com o big bang, criador de tempo e espaço. Especula-se com a idéia de nomear o materialismo de histórico e geográfico.
\end{abstract}

Palavras chave: entes geográficos, níveis de movimento e classes, conjuntura e determinação, materialismo histórico.

\section{Summary}

The text considers the historical positions of Geography, compared to other sciences, in the context of technological progress and of capitalist establishing. Of Antique origin, Geography appeared as a descriptive, narrative discipline of the Earth surface and its diversified geographical beings. Some are nature products, other are social buildings. The theoretical formulations about the movements of the real world, included the one of the geographical beings started to develop during the modernity provided by the appearance of new sciences. These new sciences also gave support to the capitalist production and accumulation, therefore winning higher hierarchy. The convergence of a set of events is contributing to the reassertion of Geography, as of History, in late contemporary times, as scientifically and philosophical sources of knowledge. It is due, among others, to the diffusion of historical materialism, to the political rise of social issues, beside the globalization and environment problems. All the movements, the natural and the social, are unfolds of one unique movement, started by the big bang, and which originates space and time. One speculates with the idea to consider materialism as historical and geographical.

Key words: geographic entities, levels of movements and classes, conjuncture and determination, historical materialism. 
Movimentos históricos do saber

A epistemologia e a filosofia da ciência têm dado atenção menor à Geografia. Esta, sendo um modo de observar e pensar desde um passado remoto, deixou de colocar a teoria como o eixo de compreensão dos seus objetos e de seus movimentos. A descrição e a narrativa ocupavam, e ainda ocupam grande parte do seu discurso. Sendo a epistemologia “a teoria da história do teórico” e sendo a filosofia, propriamente dita, “a teoria da história da produção dos acontecimentos” (BADIOU e ALTHUSSER, 1979), compreende-se esta ausência. A Geografia continua atuando entre a ciência e a filosofia uma razão para os próprios geógrafos serem tão recorrentes no trato da natureza da Geografia.

A geografia da Terra e a história da sociedade humana não foram os únicos conhecimentos que passaram a ser organizados e identificados desde o passado remoto da Antiguidade. Lembra-se o papel, na antiga cultura grega, de Pitágoras, para a Geometria, ou de Euclides, para a Física. O termo “filosofia” expressava o apreço geral por todos os conhecimentos.

No entanto, a evolução do conhecimento iria diferenciar perspectivas e modos operacionais praticados pelas diferentes ciências, levando a especializações e separação maior entre os seus praticantes.

Certas ciências passaram a depender em maior escala de invenções e da utilização de um instrumental técnico. Penetrar no infinitamente pequeno e no infinitamente grande exige o recurso a instrumentos, como fazem a Física, a Quântica, ou a Microbiologia. Cerca de 10 bilhões de dólares foram investidos na construção de um colidor gigantesco de partículas na velocidade da luz, na Suíça, na forma de um túnel subterrâneo circular de aproximadamente 30 quilômetros de perímetro. No infinitamente grande depende-se de telescópios montados sobre satélites artificiais e de veículos interplanetários.

Este reconhecimento de dimensões infinitamente grandes e infinitamente pequenas, em comparação com o tamanho do homem e com a dimensão da superfície terrestre, é um 
diferenciador da evolução científica. Camille Vallaux identificou limites para a Geografia, restringida a tratar de objetos de determinadas dimensões e acrescentou a idéia de fenômenos de massa. A Geografia trata de oceanos e rios, mas não de uma gota de água; de florestas e de savanas, mas, não da folha da árvore (VALLAUX, 1929).

Quanto ao conceito de paisagem geográfica, ele se refere a um espaço que se encontra entre o observador e a sua linha do horizonte.

Há a considerar a dimensão aparente dos objetos, dada pela distância. Os antigos não tinham a menor idéia sobre o tamanho do sol e das estrelas. Por um longo tempo, a Cosmografia permaneceu como um setor do saber geográfico. As sensações que os objetos provocam se conformam às suas dimensões, reais ou aparentes. O Claire de Lune de Debussy evoca uma Lua de dimensão aparente. Já Van Gogh criou as suas próprias dimensões de estrelas, para obter efeitos significantes.

Portanto, os modos de operar conhecimento foram se diferenciando segundo as dimensões e atributos dos seus objetos, e segundo a formulação de teorias a respeito de sua origem e movimentos. A conquista maior, ou menor de teorias diferencia as ciências.

Existe uma relação entre a introdução de um instrumental técnico para ampliar o conhecimento e a prática da experimentação. Esta consiste em repetir uma dada ação e anotar os seus efeitos, com o intento de identificar leis de causalidade. Tratar de objetos totalmente dominados por estas leis dará respaldo à identificação de ciências chamadas de exatas.

Acender um palito de fósforo depende de um atrito que produz calor que inflama uma substância inflamável, o fósforo. Porém, se o palito estiver molhado, não inflama. Os fenômenos, naturais ou sociais, dependem da articulação entre movimentos diferentes. O tempo que fecha, com nuvens, relâmpagos e trovoadas, pode não dar em chuva. No plano social, a relação direta de causa e efeito pode aparecer em momentos pontuais, porém não no processo do qual o momento pontual faz parte. No caso do movimento social, as diversas instâncias ou práticas sociais interagem umas com as outras, criando uma conjuntura e as suas determinações diversas. 
No julgamento de Nuremberg, Goering foi condenado à forca. Na véspera da execução, tomou uma pílula de cianureto e morreu imediatamente. Qual foi a causa de sua morte, naquela data e na prisão? O seu gesto com o cianureto, ou a sua atuação de liderança no nazismo alemão?

No plano social, a prática da experimentação é restrita por razões de natureza ideológica, como no caso da manipulação de embriões. Mesmo no caso de experimentos com cobaias, práticas de inoculação de moléstias, ou de mutilações, têm levantado protestos de setores da sociedade. Existem práticas repetitivas, como no treinamento, que não se confundem com o experimental, Também não se confunde o experimental com o existencial.

A prática parece demonstrar que os movimentos, ou forças, que se iniciaram na aurora do Universo, como a gravidade, a velocidade da luz são aqueles cujo estudo caracteriza as ciências exatas. Também tendem a serem exatos as ciências que lidam com corpos infinitamente pequenos ou infinitamente grandes, como a Biologia (como no caso das leis de Mandel), ou a Astronomia. Os que tratam de movimentos sociais, ou de fenômenos particulares da superfície terrestre lidam majoritariamente com conjunturas.

Efeitos da modernidade. Autonomia e integração das disciplinas

As mais expressivas mudanças conceituais no conjunto do saber humano começaram a se dar com o avanço da modernidade. Um avanço que refletia efeitos dos progressos tecnológicos e da implantação, primeiro, do mercantilismo, depois, do capitalismo. O acúmulo crescente de conhecimentos e a ampliação do seu grau de complexidade conduziam à maior especialização e conseqüente maior divisão na organização do saber. Algo que se desenvolvia em paralelo à divisão geral do trabalho provocada pela industrialização e pelo capitalismo.

Nesse processo, novas disciplinas foram sendo criadas, como a Economia, no século XVIII, com Adam Smith, da qual se originaria a Demografia. Depois viriam outras, como a Sociologia, a Antropologia, enquanto antigos campos do conhecimento, como o da Geografia e o da História, passavam por re-estruturações. 
Esta divisão do conhecimento segundo campos ou áreas diversas (área é o termo empregado pelo $\mathrm{CNPq}$ para definir distintos campos do saber) não expressa uma simples categorização formal uma vez que tem a ver com o real do Universo, o objeto último do conhecimento. É verdade que todos os sistemas de práticas e de produção se articulam e interagem entre si, integrando-se no movimento comum e único, definidor de tempos, ou de eras históricas. Contudo, a história mostra a evolução simultânea do grau de autonomia próprio a cada um destes sistemas de práticas, ou instâncias. Todos os conhecimentos fazem parte de um movimento único do saber, porém, em sua evolução, cada um deles se desenvolve por sua conta.

As necessidades da acumulação capitalista exigiam atenções crescentes do saber para as atividades orientadas para a produção material e abstrata, em detrimento da simples contemplação. O que de certo modo afetaria um comportamento simples, o de saber pelo amor ao saber, Assim a modernidade capitalista alargava também a separação entre ciência e filosofia. A ciência se ocuparia em estudar a natureza e a natureza do homem, seus movimentos e produções, enquanto a filosofia se voltaria para o sentido ôntico desta existência. Nas palavras de Deleuze e Guattari, as ciências tratam de funções, a filosofia trata de conceitos, e a arte produz os afectos, termo que eles criaram para distinguir de afetos (DELEUZE e GUATTAR, 1992). Não se deve confundir arte produtora de objetos abstratos em sua natureza, embora dependentes de suportes materiais - com a filosofia. (Esta também dependendo do suporte de uma linguagem, falada ou escrita). As artes também entraram vigorosamente no mercado capitalista.

Nos Estados Unidos, a palavra arte assume sentido maior. Os cursos de Economia, de Medicina, entre outros, se inscrevem na categoria Arts. Seus profissionais lidam com leis científicas, mas, devem recorrer, também, a especulações na tomada de decisões em relação a seus objetos.

Em suas fases iniciais, o capitalismo procurou a sua reprodução basicamente através da oferta de bens de uso material para as massas populares, valendo-se das vantagens da indústria frente ao artesanato. Depois, o crescimento proporcionado pelo capitalismo ampliou também o mercado para bens imateriais. Na contemporaneidade "a cultura passou a ser a estratégia do capitalismo em sua fase mais recente” (JAMESON, 1996). 
As artes, e agora também a filosofia, passaram a participar dos mercados das camadas populares. Um movimento que interage com nova onda, contemporânea, ou pósmoderna integradora de saberes.

A utilidade do conhecimento. Necessidade e liberdade. Conjuntura. Determinação A questão da integração e fragmentação do saber, uma das instâncias sociais, tem a ver com um outro atributo do real social. Trata-se do ser humano se dividir em indivíduos e gerações. O saber é informado entre os indivíduos e é transmitido entre as gerações. A liberdade é justamente uma expressão do grau de autonomia inerente, de que é dotado cada indivíduo, no uso da informação. É através dela que indivíduos inovadores quebram inércias no movimento do saber e dão curso a mudanças na sua direção. Por isso é dito que o saber é histórico e social. (LEFÉBVRE, 1947).

Atividades do saber, assim como as destinadas à sobrevivência e à reprodução são manifestações ônticas do ser humano, isto é, são inerentes às condições da sua natureza; à sua origem e permanência como um produto da natureza. Deste modo, estas atividades atendem a necessidades que foram ditadas originariamente pela própria natureza. É esta naturalidade que faz pensar que a prática do saber não depende forçosamente de uma necessidade identificada como uma motivação prática social.

O homem não faz mais amor apenas para se reproduzir, nem a culinária visa apenas a nutrição. O seu saber se distanciou de certas habilidades antigas, como as de lidar com as feras. Esta habilidade é agora espetáculo, exercido em circos, parques de diversão e zoológicos. No passado, o esporte era um treinamento para a guerra; depois, foi associado à saúde, porém não é por isso que os estádios esportivos se lotam. É verdade que ir ao circo ou ao estádio, praticar esportes, expressa a natureza humana voltada para a diversão, a competição e ao reviver do passado. No entanto, por não atenderem a uma necessidade específica das relações sociais atuais, deixam a impressão de que atos como pensar, não respondem a necessidades.

O circo contemporâneo é e não é um repetição do Coliseu romano. É a mesma procura do espetáculo, mas, já não serve a intentos políticos similares. As novas conjunturas 
históricas interferem no sentido das atividades, e a idéia de necessidade adquire o conceito de ser também associada ao movimento social. O homem urbano, contemporâneo, freqüentador de caixa eletrônica precisa saber manejar o elementar da lógica, da linguagem da informática e da linguagem matemática.

Portanto, é verdade que o homem pensa porque é de sua natureza pensar; mas, é, também, verdade que ele pensa para satisfazer as necessidades que se lhe apresentam. $\mathrm{O}$ pensamento de cada indivíduo espelha a conjuntura da sociedade em que se encontra, bem como, reflete suas linhagens de natureza cultural e biológica.

O sendo de qualquer indivíduo envolve o seu futuro, o seu presente, e o seu passado. O homem é dotado de liberdade, porém, não de livre arbítrio, enunciado já realizado por Baruch Espinosa. (ESPINOSA, 1979). Deste modo, em relação ao futuro, o homem pode se mover como um navio. Ele possui suas amarras que o atracam e desatracam a portos oferecidos pela sociedade, Quando desatraca navega para um outro porto, ou cria um novo porto. A sociedade é como o continente onde os portos estão localizados. Ela apresenta uma série de práticas, instâncias, entrelaçadas, constituindo uma conjuntura. Consideradas suas funções no movimento social, as instâncias são classificadas em econômicas, políticas, ideológicas, sócias propriamente ditas, e culturais. A conjuntura se define pela determinação de uma dada instância, ou combinação de instâncias. A identificação das instâncias determinantes é essencial no estudo de uma sociedade, pois, através da mesma se traça uma linha de análise racional para a sociedade em questão. A determinação é o efeito que uma conjuntura exerce sobre o indivíduo, ou grupo de indivíduos, membros de uma sociedade.

\section{A antiguidade de Geografia e História}

As questões que vem sendo expostas se destinam a oferecer entrada para o significado da Geografia e da História, como saberes de enorme antiguidade. Elas surgiram numa época sem sistematização científica, sem construção de edifícios teóricos. Seguiram mais pela linha da descrição e da narrativa. A idéia de história apareceu no passado longínquo associada à capacidade humana de memorizar imensa quantidade de acontecimentos, estabelecer a sua duração, seqüência-los logicamente, concatena-los e utiliza-los moralmente. Expressava a vivência temporal. A idéia da geografia aparece associada à identificação racional das qualidades dos lugares, e de grupar os lugares 
segundo propriedades comuns. À capacidade de identificar uma geometria desenhada pelas localizações e grupamentos de lugares; de ajustar a atividade social às condições naturas dos lugares. Os tempos e os lugares passaram a ganhar nomes comuns, como semana, mês, rio, mar, montanha, cidade; e nomes próprios, como Sábado, Páscoa, Jordão, Sinai, Mesopotâmia, Ur.

A Bíblia já descrevia diferenciação regional: “a terra em que vais entrar para dela tomar posse não é como a terra do Egito de onde saíste, onde lançavas a semente e as regava pedalando com os pés, como se rega uma horta. A terra que vais ocupar é uma terra de vales e montes que bebe a água da chuva do céu” (DEUTERIMÔNIO, cap.11, versículos 10 e 11). Contudo, a queda da chuva dependeria da vontade divina.

A articulação dos saberes da história e da geografia aparece de forma emblemática na frase de Heródoto, “o Egito é um dom do Nilo”, onde o Egito é um ente geográfico e histórico, socialmente construído e o rio Nilo é um ente histórico e geográfico produzido pela natureza. Dois entes de uma unidade, histórica e geográfica, cada um, dotado de um grau de autonomia. O rio surgiu antes dos tempos históricos e a sua presença influi para a construção do Egito. Na atualidade, o Egito fez barragem sobre o Nilo e construiu a imensa hidrelétrica de Assua. Os dois continuam interagindo. Porém, o rio Nilo continua dependendo das chuvas tropicais no seu alto curso e a economia do Egito depende do seu regime social.

No Universo, igualmente, movimentos mais recentes tendem a modificar quadros anteriores, pela introdução de novos objetos e de novos movimentos. Os objetos e movimentos anteriores persistem, mas, podem ser alterados. A formação vegetal, por exemplo, além de influir no movimento climático, produz micro climas segundo os diversos ambientes fitogeográficos. O ambiente urbano construído, também, é criador de modalidades de micro climas.

Ao longo da história foi sendo registrada a multiplicação crescente de níveis de movimento, na natureza e no interior do movimento social geral. O filósofo grego Demócrito, objeto da tese acadêmica de Marx, especulou sobre a estrutura molecular do Universo, cuja comprovação prática só seria realizada na modernidade. A descoberta de Pasteur de micro organismos e das moléstias por infecção só ocorreu no século 19. O 
fato é que o saber foi acumulando volumes gigantescos de informação enquanto construía objetos de conhecimento cada vez mais numerosos e complexos. Paralelamente, a vida social foi se tornando mais variada e complexa. Nestas condições, seria difícil para a Geografia e para a História arcar com a responsabilidade dos estudos de tantos níveis de movimento sendo detectados. Estudos que exigiam uma linguagem matemática sofisticada e novos métodos de trabalho, como os que se realizam em laboratórios especializados. A especialização conduziu a uma separação entre a Geografia e a História.

O adensamento do meio técnico e científico. Capitalismo

A especialização e a complexidade crescente do saber durante a modernidade foi se fazendo com a ampliação de um instrumental técnico produzido pela sociedade humana. Este instrumental técnico era destinado a ampliar a capacidade humana sensorial e de trabalho, oferecendo maior curso ao seu pensamento e à sua produção. A utilização da luneta por Galileu, pela qual poude constatar que é a Terra que se move em torno do sol, foi um momento de abertura da utilização sistemática de instrumentos técnicos na ciência. A invenção da máquina, no século 18 abriu a era industrial e deu ensejo ao estabelecimento do capitalismo.

A invenção da máquina exigiu o apuro da linguagem matemática, uma vez que os seus movimentos se realizam segundo operações quantitativas. A linguagem é também um instrumento técnico. A evolução da matemática na modernidade acompanhou a evolução das demais instâncias sociais. Ela foi imprescindível para o avanço do capitalismo, no seu afã de substituir o mundo natural por um mundo de objetos fabricados. Galileu dissera que “a matemática é a língua utilizada por Deus para construir o Mundo”. O homem a utiliza para continuar esta construção. Com a utilização da matemática são refeitos os caminhos do Universo, desde o big bang.

O desenvolvimento econômico e social, também, exigiu os conhecimentos matemáticos. Existiu uma relação entre a descoberta do cálculo da probabilidade. e a necessidade de se calcular o seguro dos navios e de suas mercadorias, quando do crescimento do comércio marítimo depois dos grandes descobrimentos (HOGBEN, 1939). A estatística, 
um dos setores mais recentes do campo matemático, capaz de reduzir gigantesca massa de informações a uma expressão simples, é um instrumento próprio para realizar experimentos, testes, e aferir indicadores sociais.

A contemporaneidade é marcada pela presença do computador pessoal, produtor de informação quantitativa e qualitativa, mas, que para produzi-la, opera na linguagem quantitativa. Através da informática, o computador reproduz e estende a capacidade de operacional da racionalidade humana.

A informática faz o meio tecnológico alcançar um momento impar. Ela reproduz em quantidades e velocidades fantásticas operações que podem ser direcionadas para fins múltiplos. A informática pode ser utilizada na linha da produção material operando robôs; pode ser utilizada em serviços, como no controle dos vôos aéreos; ou ser direcionada para a pesquisa pura. A informática como que reproduz uma capacidade do ser, a de articular, num movimento único, uma avaliação e tomada de decisões, e transforma-las em ações. Uma articulação que, no nível humano, define necessidades e promove sua satisfação.

O capitalismo e os intercâmbios de instâncias e usos.

O adensamento tecnológico promovido pelo capitalismo ampliou o número de articulações e intercâmbios entre as diversas instâncias sociais. Facilitou, também, usos polivalentes de objetos produzidos.

Um exemplo marcante da relação entre a introdução de novos objetos e as mudanças no curso da história foi dado pelo uso da pólvora na Europa. Trazida da China, onde foi inventada e utilizada para a queima de fogos de artifício, passou a ser utilizada em armas de guerra, derrubando muralhas de cidades e castelos medievais, evento fundamental na passagem de regimes medievais para regimes da modernidade.

Um exemplo ilustra o quanto o homem pode alterar a função de um objeto Na passagem da modernidade para a contemporaneidade, na França, numa exposição de arte, Duschamp colocou um urinol, de fabricação industrial, numa posição invertida, tornando o ato um momento emblemático da história da cultura. A troca dos fins 
alcança inclusive objetos imateriais. No dia D, da Segunda Grande Guerra, à véspera da invasão da Normandia, versos da inspiração poética de Verlaine foram utilizados pela BBC como código de alerta para a Resistência francesa.

Por outro lado, a produção material mostra uma quantidade de objetos semelhantes serem direcionados para fins diferentes. As lentes são fabricadas para óculos e lupas, para ajudar a vista em atividades do cotidiano. Outras lentes são fabricadas para microscópios, se destinam à pesquisa especializada.

Em tal meio técnico, de articulações, superposições, trocas, não há que estranhar que conhecimentos produzidos por uma ciência passassem a ser utilizados por outras ciências. Como no caso do uso tão freqüente da teoria da centralidade urbana por geógrafos, iniciada pelos economistas Lorsch e Christaller. Sem dúvida os intelectuais brasileiros da Semana Moderna, em São Paulo, última secada de 20, acertaram em cheio, quando chamaram o seu manifesto de, Antropofagia.

A superposição de disciplinas diversas sobre um mesmo tema cria um efeito semelhante ao da superposição de fotografias de um mesmo campo, para produzir uma terceira dimensão em forma virtual. A superposição de saberes amplia o volume do objeto considerado e das informações que se referem ao mesmo.

Na contemporaneidade, estes movimentos de articulações e de superposição de ciências desembocaram em novos recortes disciplinares e na criação de campos de atividades interdisciplinares e multidisciplinares.

\section{A competição capitalista}

A intensificação da densidade tecnológica e do uso de produtos industrializados em todas as formas de consumo tem re-alimentado a contínua acumulação capitalista. A introdução de novos produtos, ou de seus novos modelos, a prática de destruições criativas tem servido para a superação de lucros decrescentes, de declínios nos ciclos produtivos, de desajustes entre meios e relações de produção, provocadores de crises. Esta movimentação acionava o andamento da economia, a mobilidade social e o 
movimento político e ideológico. Enfim, vem movendo, até agora, a história no seu todo.

O capitalismo compreendeu o desenvolvimento de um poderoso setor de negócios formado por empreendedores privados. Desenhou contornos relativamente muito nítidos, separando os setores público e privado, na economia e na sociedade. Concebeu o setor público a serviço da sociedade, rompendo com o direito divino dos reis, vigente desde a Antiguidade. De certo modo, a construção de uma sociedade civil relativamente independente do Estado iria repor um quadro passado, e que fora retirado pela Idade Média. O capitalismo proclamaria um regime democrático, próximo ao experimentado na antiga Atenas, inclusive, o seu culto por um saber livre de pressão clerical. No entanto, as proporções sociais numéricas eram totalmente diversas forçando a substituição da democracia direta pela democracia representativa.

O mercado capitalista também era diferente dos antigos mercados quanto a forma de produzir lucro. O próprio conhecimento passou a fazer parte do mercado e de suas competições por lucro. A idéia do lucro foi incentivadora de avanços tecnológicos e de especializações, utilizados na competição capitalista. A modernidade dirigida pelo capitalismo conduzia à maior fragmentação do saber e a competição entre os diversos setores. Foram identificadas as linhagens das ciências, da filosofia e das artes (DELEUZE e GUATTARI, 1992). Cada um desses campos foi criando o seu sistema de produção e o seu mercado.

No entanto, para se reproduzir e se expandindo pelo mundo, o capitalismo não poderia promover apenas fragmentação. De um lado, ele acirra competições entre os empresários de um mesmo setor de atividades, e entre os diversos setores de atividades que compõem o capitalismo. De outro lado, a sua instalação como modo de produção dominante na escala global só pode se realiza através de um outro movimento, unificador e aglutinador. É este último movimento o que confere a organicidade de sistema. Esta aglutinação não se refere apenas aos movimentos da superestrutura do capitalismo, isto é, ao estabelecimento de ideologias, alianças, pactos, para sustentar o capitalismo. Na própria prática econômica capitalista assiste-se a dois movimentos que 
lhe são próprios: a multiplicação contínua de novos empreendimentos e a absorção de negócios menores por negócios maiores, que chegam a formar empresas gigantescas. Trata-se, portanto, de uma organicidade que compreende sistemas de componentes hierarquizados. As empresas menores expressam a multiplicação demográfica, ou a urbanização, ou ainda, a germinação de novas criatividades. É entre estas últimas que, via de regra, aparecem os crescimentos em cogumelo, que as elevam para a hierarquia maior, igualando-as às grandes empresas e corporações.

A natureza orgânica também é provida pela construção de uma superestrutura. A superestrutura capitalista compreende a simultaneidade de movimentos homogeneizadores e diversificadores, os primeiros de maior hierarquia, O capitalismo difunde a sua homogeneidade pelo mundo através do consumismo dos seus produtos e pela adesão aos seus modelos ideológicos de democracia política,

Nas sociedades capitalistas e modernas cada individuo pode pensar e se comportar a seu modo, a homogeneidade reside na idéia de que este valor deva ser universal. É o lema capitalista da unidade da diversidade Nas sociedades tradicionais a diversidade só pode existir fora de cada uma delas. No seu interior, a homogeneidade é imposta a todos os seus indivíduos. É o lema da diversidade da unidade.

O capitalismo não prescinde do Estado, apesar de estar centrado no setor privado da economia e de enfrentar conflitos freqüentes com o mesmo. Capitalismo é, por princípio, comportamento alternado de compromissos e de radicalismos O Estado é um gestor do espaço geográfico onde o capitalismo opera, ele se ocupa das necessidades coletivas da população, como a demanda por equipamento urbano e social. Ele pode ser aliado, ou mediador em conflitos de interesses entre setores empresariais, ou entre os empresários e outras classes da sociedade. Enquanto não é estabelecida uma governança mundial, o Estado tem servido para pressões e intervenções em confrontos entre capitalistas de países diferentes.

O capitalismo mostra interesse no fortalecimento de certas funções do Estado e no enfraquecimento de outras. Uma série de acontecimentos contemporâneo, de interesse capitalista, e que compreendem acordos formais para novas formas institucionais, são 
promovidos através do Estado. É o caso dos blocos de países em mercado comum, oi da formação de união política e econômica, como a União Européia.

Estes desenvolvimentos vem ocorrendo num quadro mundial de forte transição do modo de produção, que está sendo invadido de componentes de origem socialista, particularmente concernentes à seguridade social. Note-se a luta política feroz em andamento nos Estados Unidos, em torno da questão da seguridade de saúde universal. O sistema inteiro capitalista passou a apresentar paisagem híbrida, com o lugar crescente que nele vem ocupando a China, dirigida por um Partido Comunista. Inclusive, o Estado está se tornando um instrumento de movimentos internacionalistas, como nas articulações do chamado G-20, para um enfrentamento coletivo da crise do sistema capitalista desde 2008.

As articulações contemporâneas do setor privado do capitalismo com o Estado se realizam quando a hierarquia maior da empresa capitalista toma a forma da corporação. Não cabe neste texto elaborar a respeito das empresas corporativas. Será notado apenas, que, nos Estados mais desenvolvidos, é cada vez mais comum, os executivos ocuparem, alternadamente, posições nas empresas e na administração pública. Ou seja, assim como notado antes, que um mesmo objeto pode ser encaminhado para usos diferentes, do mesmo modo, um quadro de alta qualificação pode migrar entre diversas ocupações dos setores público e privado.

O progresso científico e tecnológico observado na modernidade e continuado na contemporaneidade, também chamada de pós-modernidade, povoou tanto o setor privado, como o setor estatal. Na economia privada, o crescimento do setor financeiro e da forma corporativa expandiu o conhecimento, não só nas áreas da engenharia da produção industrial, como nas áreas da administração empresarial e financeira. Quanto ao setor estatal, a gestão de seus serviços, do território, e dos seus recursos financeiros, também assumiu forma mais sofisticada. A migração de quadros passou a se realizar, também, entre a Universidade e a administração pública, assim como entre a Universidade e o setor privado. O Plano Real de 1994, foi criado por um grupo de professores de Economia da PUC - Rio chamado ao poder federal. 
Numa tal paisagem econômica e social, a competição entre os indivíduos, ou entre grupos de pessoas de um mesmo metiér, por posições em empresas ou em governos, por subsídios, ou verbas para pesquisas, foi intensificada. À falta de argumentos técnicos se apelava a razões ideológicas. A competição também se intensificou entre as diversas disciplinas, dispostas a mostrar a sua maior valia para o desenvolvimento, seja no setor da produção e venda de mercadorias, seja no setor da gestão administrativa. Certas disciplinas passaram a dominar certos setores de atividades, como por exemplo, a Biologia e a Química na área da farmacologia.

O surgimento de diversas disciplinas novas aconteceu justamente neste contexto competitivo, produtor de níveis mais elevados de especialização. Foi assim que a Geografia foi tomada por um movimento de retraimento, quando diversos dos seus campos de estudo, como a Geologia, a Pedologia, a Climatologia, a Oceanografia, a Agronomia, assumirem status de disciplinas autônomas. Quanto à Geografia como um todo, passou a fornecer informações para as estratégias políticas espaciais do capitalismo e do Estado, o que levou Yves Lacoste a escrever, em 1976. a conhecida frase de que a Geografia é para fazer a Guerra.

A lista acima, e que cobre apenas parte do vasto campo de interesse da Geografia, é indicativa da dificuldade de ser trabalhada por um único pesquisador. O que, aliás, ocorre, na contemporaneidade, com qualquer ciência. O título do livro de Camille Vallaux, Les Sciences Geographiques, expressava a idéia de estabelecer um campo de ciências geográficas, ao lado dos campos de ciências naturais e ciências sociais.

Durante o Congresso Internacional de Geografia da UGI no Rio de Janeiro, 1982, a contribuição da antiga União Soviética seguia por esta linha. Ciências geográficas seriam aquelas cujos objetos estariam sujeitos aos princípios da zonalidade, Isto é, cujos atributos variariam influenciados pela esfericidade e movimento da Terra e pela inclinação do seu eixo em $23^{\circ}$ e $27^{\prime}$. Fenômenos como a gravidade e a velocidade da luz, não são influenciados pela zonalidade, pertencem às ciências naturais. As classes sociais, também não o são. O clima a formação vegetal, as formas tradicionais de práticas agrícolas são regidos pela zonalidade.

Percebe-se que o princípio da zonalidade se encontra mais presente no espaço dos objetos naturais e menos no campo social. O homem introduz técnicas, como a 
adubação, cruzamentos de espécies, construção de estufas, que tornam a agricultura menos sujeita à zonalidade. Com efeito, a Geografia soviética era profunda na área da Geografia Física, e se limitava a citar as realizações do Estado, na parte social. Expressava a falta de liberdade, imposta pelo regime, no trato das ciências humanas (a psicanálise, por exemplo, era proibida). Por outro lado, se encontrava em conformidade com o marxismo da época, que, fiel aos ideais de totalidade, concebia uma única ciência social, a Economia Política. Geografia, Antropologia, Sociologia, seriam seus setores, seus capítulos.

Na forma de uma ciência única, a Geografia encontrava maiores dificuldades na disputa com outras ciências no que tange ao saber analítico. Tendo aparecido como um saber descritivo, a Geografia e as ciências dela desdobradas foram tomando, emprestadas, as leis elaboradas por outras ciências, para explicar os movimentos dos seus objetos. Como ciência unificada, o discurso da Geografia procura fazer uma síntese dos conhecimentos produzidos pelas ciências que delas se originaram e dos conhecimentos de outras ciências, notadamente os da ciência social. Esta síntese terá sempre a presença dos entes geográficos, sejam rios, florestas, cidades, regiões, países, e outros. O discurso unificado e menos teorético tende a conduzir o conhecimento para a filosofia. No plano analítico, temas tradicionais do trato geográfico, como a regionalização, a urbanização, e outros, passaram a se disputadas e ganhas por arquitetos, economistas, sociólogos, cientistas políticos.

A fantástica expansão do mercado de produção e de consumo de materiais científicos, nas condições do capitalismo, se manifestou naturalmente na multiplicação dos candidatos a competir por estes mercados. O sistema acabou criando espécie de cortes julgadoras e controladoras do que poderia e do que não poderia ser legitimado como produção científica e ser aceito no mercado. Passaram a ser definidas regras, princípios para que qualquer produto pudesse ser classificado como científico. Desenvolveram-se a Epistemologia e a Filosofia das Ciências. Um controle semelhante se instalou nas Artes, responsável pela rejeição dos primeiros pintores impressionistas no salão oficial de Paris. Tal controle é menos possível de ocorrer na área tecnológica, onde a validade e o sucesso dos inventos são testados em sua utilização prática. Outras formas de controle foram instaladas, como as legislações que tratam de patentes e de plágios. 
O texto presente vem tratando do rebatimento do modo de produção sobre instâncias relacionadas ao conhecimento e ao saber. No entanto, como qualquer instância, o saber não é somente uma instância passiva, ele interage com as outras. O saber não é apenas conformado, ele conforma, age sobre o modo de produção.

Não existe, aliás, um modo de produção 'puro' Ele sempre incorpora componentes de modos idos, e passa a carregar sementes dos futuros. Uma razão para a criação do conceito de formação econômica e social, que se refere à realização concreta de um modo de produção. Este último é um conceito mais abstrato, que se refere à forma de relações sociais no processo produtivo. A formação social se refere ao quadro resultante da articulação destas relações de produção com todas as instancias sociais, num dado tempo e num dado lugar. Um quadro que expressa a história do lugar e os seus potenciais para mudar.

Consequentemente, o sistema do conhecimento e do saber apresenta sua conformidade ao quadro existente num dado lugar. Isto é, apresenta a face que tende à manutenção da formação social em suas características presentes e apresenta a face que pede mudanças. Via de regra, isto significa que o lugar é aberto para se articular com o mundo externo ao mesmo.

Em cada lugar, em escalas diferentes, o saber e o sistema do saber são influenciados tanto por formas de pensar pré-capitalistas, como pela presença de movimentos de transição e mudança do modo capitalista. O panorama mundial, já foi mencionado, aponta experiências com relativo sucesso de transições e de formas híbridas de capitalismo e socialismo, como no caso citado da China. O campo do centro histórico do capitalismo se encontra invadido por legislações de inspiração socialista. No presente, apresenta a entrada em cena de formas empresarias que destoam das formas clássicas capitalistas, como é o caso da expansão das chamadas indústrias criativas.

O próprio saber participa das transições dos sistemas, inclusive no seu próprio, através de setores atentos para a crítica, à cada momento de um sistema, e propondo mudanças. Na questão ambiental, por exemplo, vem sendo realizada uma crítica a todos os modos de produção presentes e proposições válidas para qualquer um. 
A propósito, abre-se um parêntesis, para apontar fracassos recentes associados ao menosprezo das leis do movimento social. Em sua A Ideologia Alemã Marx foi muito claro ao descrever o desenvolvimento do capitalismo através das articulações entre instâncias e lugares diversos. (MARX, 1996). No entanto, o stalinismo vendia a idéia de sua implantação a partir da vontade do núcleo stalinista, à semelhança do bonapartismo sonhando impor a revolução francesa pela força. A China mostra ter aprendido a lição.

\section{A volta por cima da História}

No pensamento de Haidegger, o futuro se encontra não só no presente, como no passado. O termo socialismo aparece desde o século 19, assim como o conceito de modo de produção. Aos quais irá se juntar a idéia de materialismo histórico. Numa época de aceleração de transformações e inovações tecnológicas, e considerando os já 200 anos do surgimento da idéia socialista, muitos desdenham da possibilidade de movimento do modo de produção. No entanto, deve se levar em conta que todos os antigos modos subsistem de alguma maneira, apesar da dominância atual do capitalismo. Que a dominância de qualquer novo modo levou séculos para se instalar. Que a tremenda força orgânica do capitalismo é superior à de qualquer forma anterior. Inclusive pela densidade dos laços estabelecidos entre as diversas instâncias, e das articulações de natureza geográfica. Por outro lado, ainda falta uma distância crítica para a avaliação das invasões mais recentes de componentes socialistas mesmo nas áreas mais centrais do capitalismo. Veja-se a luta feroz nos Estados Unidos valendo-se de temas como o da seguridade social universal.

Marxismo e materialismo histórico aparecem como contradição dentro do capitalismo, mas, assumindo a sua postura de minimizar a filosofia, a favor da ciência. A filosofia, como sistema, é uma herança de passado longínquo. A ciência como sistema é da revolução capitalista. Caberá ao próprio materialismo, cientificista, que concebe a totalidade independente do monoteísmo, reintegrar ciência e filosofia, objeto e sujeito.

O reencontro se realiza quando o materialismo histórico se instala como espécie de filosofia para qualquer atividade científica. De modo simples se dirá que o materialismo histórico consiste em considerar que o real é o conhecido pelo homem, nas interrogações e experimentações que realiza em relação à natureza e a si mesmo. Que, na medida em que estas interrogações e experimentações se realizam ao longo da sua 
história, o real evolui historicamente para o homem. Neste sentido, há uma relação entre as mudanças históricas da percepção do real e as mudanças das conjunturas históricas. Um setor marxista designado de estruturalista distingue o materialismo histórico e o materialismo dialético. O primeiro, como ciência, acompanha o movimento da relação histórica das instâncias, de certa forma competindo com a Economia Política. Ele propõe substituir a idéia da teoria do conhecimento pelo da história do conhecimento $\mathrm{O}$ segundo, observa as leis do movimento do primeiro, espécie de filosofia do primeiro. (BADIOU e ALTHUSSER, 1979). Esta linha recebe críticas de outros setores marxistas, o materialismo histórico sendo considerado já como uma filosofia da ciência.

O desenvolvimento do pensamento marxista e do materialismo histórico e dialético envolveu a filosofia, a ideologia, a política, enfim todo o pensamento social. Ele se encontra por trás de uma frase, como a de Oscar Wilde, de que o fog londrino só passou a existir depois da tela pintada por Turner. Portanto, este desenvolvimento não se dirigiu para a disciplina História em particular. A Economia Política é que se tornou a disciplina central do pensamento marxista. A ela caberá definir a conjuntura universal de cada momento, e seus movimentos de determinações, cabendo à História detalhar o quadro formado em cada momento em cada lugar.

No entanto, contribuiu para novos desenvolvimentos para a História, do mesmo modo que para a Geografia. A História abandona a prática simples de narrativa de acontecimentos, tratando cada vez mais das articulações das diversas instâncias para as suas realizações. A articulação do movimento histórico com o movimento geográfico, por exemplo, assume um novo relevo na produção de Braudel (BRAUDEL. 1996). O ente geográfico já passara a ser citado como um componente do movimento da história, na frase mencionada de Heródoto. E relativamente esquecido. Agora a questão era aprofundada em termos científicos e filosóficos.

A reasserção do espaço, e a Geografia

Espaço e tempo surgiram inseparáveis, dede a criação do Universo, como o modo de ser da matéria. No entanto a vivência sensorial da matéria pelo homem distingue um do outro, O tempo lhe aparece como fugaz a cada momento de sua vida, como movimento 
abstrato. Já o seu corpo lhe aparece como concreto, materializado. Aos poucos, percebe que o seu corpo também contém o tempo, que se altera continuamente.

O materialismo histórico colocou em primeiro plano o tempo social. Com o conceito de formação econômica e social, a espacialidade, também, passou a ser valorizada pelo materialismo histórico (SOJA, 1989). A questão do espaço geográfico, como observado, anteriormente, na referência a Braudel, deixou de encarar os objetos geográficos como simples resultados, como artefatos produzidos pelo homem, ou como objetos produzidos pela natureza. Eles passam a ser entendidos como componentes do processo histórico social. A própria idéia de primeira e segunda natureza é superada, quando se assume que o simples olhar humano sobre a natureza já é o início de sua inserção no movimento social.

Portanto, o observado para a História vale para a Geografia. A valorização da espacialidade na pós-modernidade envolve todos os campos do conhecimento, se aplica a todos os saberes. Lidar com o espaço da tela é importante para o pintor; a disposição espacial dos instrumentos da orquestra é primordial para a execução da música sinfônica. O que a Geografia pode proclamar é a sua antiguidade em enfatizar o espaço geográfico e apontar para o espaço materializado e produzido pelo homem como componente do materialismo histórico. Beste sentido, ela exerce um papel filosófico. Como ciência, o seu objeto se restringe aos espaços geográficos, seus objetos, os entes geográficos, e suas formas. Por espaço geográfico é entendido todo aquele habitado pelo homem que poderá se situar fora do planeta, num futuro.

Heidegger (1993) referiu-se a fundamentos básicos de uma ciência. Qualquer ciência, em sua evolução, pode criar novos, ou pode reformular os seus fundamentos, mas haverá fundamentos básicos que, se abandonados, fazem aquela ciência mudar de identidade. São como uma “certidão de nascimento”. Como numa Constituição, onde os artigos pétreos não podem sofrer emendas, apenas através de uma nova Assembléia Constituinte, vale dizer, numa nova Constituição.

No caso da Geografia, seu fundamento básico é que o seu objeto, o espaço geográfico se compõe de entes produzidos pela natureza, alterados por sua presença, e de entes 
geográficos produzidos socialmente. Se o método de uma ciência expressa "a relação que a teoria mantém com o seu objeto, na aplicação ao mesmo”, resulta que o método da Geografia consistirá em tratar das relações entre o movimento das formações econômico e sociais e os movimentos dos seus entes geográficos.

Milton Santos chegou a propor a inclusão da expressão e espacial, para o conceito de formação econômica e social. Julga-se, no entanto, imprópria tal proposição, pois o termo formação, composto de forma - espaço - e de ação - tempo - já contem a idéia. Melhor será pensar na inclusão de espacial, na expressão do materialismo histórico materialismo histórico espacial.

Calcula-se o tempo de aparição do homem em milhões de anos. Um movimento relativamente recente na história da natureza. Para a superfície terrestre, contendo seres vivos, consideram-se centenas de milhões de anos. Para a origem do Universo, segundo a teoria do big bang, 14 bilhões de anos. O materialismo histórico e geográfico como que enfatiza os movimentos do homem nos dois sentidos. Ao revés, de trás para frente, da atualidade para a profundidade do passado, e para frente, já iniciando a era interplanetária.

Na Geografia este olhar simultâneo, para trás e para frente, se encontra implicitamente presente quando considera uma Geografia Física e uma Geografia Humana, ou Social, Se a Geografia, para muitos, é essencialmente social, trata-se, apenas, para colocar o futuro à frente do passado. $\mathrm{O}$ fato de o presente conter passado e futuro, assim como o futuro compreender passado e presente, se encontra manifesto na crescente centralidade da questão ambiental. A questão ambiental não é um tema exclusivo da Geografia. Nem é ela quem dispõe do arsenal técnico para analisar os movimentos que ocorrem na economia e nas suas relações com a natureza. No entanto, assim cimo a História sintetiza numa narrativa o estado geral de uma conjuntura, na base de informações fornecidas por outras ciências, a Geografia exerce papel semelhante. Ela sintetiza numa narrativa única os múltiplos aspectos altamente complexos que ocorrem nas articulações do espaço geográfico, e que lhe são informadas pelas outras ciências. Todas as ciências se realizam através de análises e se sínteses, Mo caso da História e da Geografia, o que 
as caracteriza é o grau de dependência das análises providas por outras ciências. Esta seria a razão de terem sido alvo menor da Epistemologia e da Filosofia das Ciências.

Níveis de um movimento único. Por um materialismo histórico e geográfico O texto aqui apresentado provoca indagações. Por que os movimentos apresentam a dialética de forças em contradição em todos os processos do Universo? Por que num mundo tido como uma totalidade, qualquer movimento se desdobra em um número infinito de movimentos? Por que todos os objetos e fenômenos ocorrem em espaço e em tempo?

Não se julga possível uma resposta aos por que do mundo ser assim, porém, na contemporaneidade, parece possível descrever como ele se tornou assim e fixar o momento no qual começou a ser assim. Que é o momento mesmo da criação do Universo.

\section{Níveis de movimentos}

O início de movimento, pela teoria do big bang (HAWKING, 1988), é a explosão no meio do nada, de uma singularidade, um corpúsculo infinitamente pequeno e denso, de dimensões inimagináveis, e que foi a origem de todo o Universo. O movimento causado pela explosão continua, além de se desdobrar em novos níveis de movimento. A explosão e o início do Universo são datados para cerca de 14 bilhões de anos passados. A explosão laçou as partículas elementares formadoras do Universo que passou desde então a se expandir e que continua se expandindo. Este movimento primeiro, a expansão do Universo sobre o nada, é o criador de espaço e de tempo.

A explosão inicial criou os primeiros corpos materiais, as partículas elementares, e o seu movimento de expansão. Criou-se, assim, espaço e tempo. A explosão é narrada pela ciência da Física, como uma espécie de replica ao Gênesis, Este movimento inicial provocou um começo de encontros entre as partículas, produzindo choques, fragmentações, condensações, criadores de novos corpos, de tamanhos variados. Surgiram as nebulosas, as estrelas, os buracos negros, os planetas. Cada um destes novos corpos, ou conjunto de corpos, alterava a inércia dos movimentos anteriores e introduzia novas formas de movimento. Passaram a se manifestar as forças da 
gravidade, da luz, da energia, a revolução de astros em torno de outros astros e em torno de seus próprios eixos, etc. Cada novo movimento criado por cada novo corpo passou a conter o seu próprio espaço e o seu próprio tempo. Numa longa viagem interplanetária, em altas velocidades, ao voltar à Terra, um astronauta poderia encontrar uma nova geração de habitantes, não mais a sua.

As partículas se encontram por toda parte. Constituem os átomos de moléculas das rochas da crosta terrestre, e os átomos das células dos seres vivos. E todos nós, os homens e o seu planeta fazemos parte de um Universo que continua se expandindo sobre o nada.

O fato de que, desde a origem do Universo, a criação de um novo objeto por um dado movimento origina um novo movimento que introduz novo objeto que cria novo movimento, infinitamente, e alterando os quadros anteriores, pode ser o ponto de partida para o entendimento da dialética.

A idéia da formação de novos objetos, que criam novos movimentos, interferindo em movimentos anteriores, pode ser aplicada aos movimentos sociais. Deste modo, se entende que ao longo da história, além dos confrontos de duas classes, uma dominante e uma dominada, que caracterizam cada modo de produção, há de se considerar o aparecimento de uma terceira classe, à margem desta dualidade, e que expressa o surgimento de um novo objeto e de um novo movimento. A nova classe se alia ao setor dominado anterior na disputa pelo poder de classe dominante.

Exemplifica-se: ao ser inventada a agricultura, um novo objeto, os campos cultivados passam a ser protegidos dos movimentos livres de coletores e pastores. A fixação do homem ao território fez surgir a propriedade privada e a sociedade de classe, que na era agrária separou senhores de terras de trabalhadores da terra. Mais tarde, com a caravela, com os grandes descobrimentos, o crescimento do comércio sustenta a ascensão da cidade, dos mercadores e dos banqueiros, tema de o Mercador de Veneza de Shakespeare. Não foram os servos da gleba que se elevaram com o fim do feudalismo, mas, uma terceira classe, a classe mercantil, logo transformada em capitalista. Sob mercantilismo e capitalismo, o destino dos servos melhorou, transformados em 
camponeses, embora enfrentando novas lutas Aliás, senhores de terra também se transformaram em capitalistas, fato bem observado no Brasil, na sua passagem do regime agrário para o regime industrial. Quanto ao capitalismo, a contemporaneidade mostra a expansão dos serviços, enquanto o chamado proletariado industrial se reduziu extremamente, em termos absolutos e relativos. Os serviços da atualidade se destacam pelos setores designados de serviços qualificados que reúne grande massa de assalariados, muitos, aliás, com padrão capitalista de consumo. A força oposta ao capitalismo histórico, na atualidade, não é mais a classe histórica operária, é a dos assalariados, que reúne gente ganhando de salário mínimo a fortunas. São os assalariados gestores do capital, no setor público ou privado, os que conduzem o movimento da globalização atual.

Criada a vida, criou-se o movimento da informação e da linguagem, A informação já se encontra no movimento das células, por exemplo no DNA. A novidade do momento é a concepção de informação mesmo no mundo inorgânico. O que faz que na natureza, assim como no laboratório, a produção de uma molécula de água sempre une dois átomos de Hidrogênio a um átomo de Oxigênio? Se, como afirmou Galileu, a matemática foi a linguagem de Deus para construir o mundo, a informação quântica seria a linguagem da natureza?

Uma nova teoria surgida no campo da Física postula que o Universo seria composto de unidades básicas à semelhança de bits de informação, e que o Universo funcionaria como um gigantesco computador quântico. (VEDRAL, 2010). Uma resenha sobre o livro publicada no The Economist diz que deste modo visões religiosas são reintroduzidas, ao se argumentar que a informação pode ser criada a partir do vazio (THE ECONOMIST, 2010). Note-se que estas teorias não podem deixar de trazer à memória figuras ilustres do passado que por isso mesmo foram chamados de Pensadores. Como aquele que via Deus como a imanência da natureza (SPINOSA, 1979). (Existem muitas outras teorias relativamente novas na Física contemporânea, como as que tratam da existência de vários universos, da existência de matéria e da anti-matéria, etc. , mas, que não cabem ser introduzir neste texto).

A superfície geográfica continua sendo a única região conhecida do Universo que apresenta continentes e oceanos e os seres vivos. Trata-se portando de uma região 
privilegiada caracterizada pela quantidade de movimentos que aí foram sendo superpostos, em particular os movimentos associados à presença do homem, ou seja, os movimentos sociais. A fonte do reconhecimento, ou da existência deste mudo que está sendo descrito, é a natureza do movimento de reflexão consciente que passa a se realizar com a presença da espécie humana. Neste sentido, mais do que um ente, o homem é o ser (HEIDEGGER, 1993).

Se o código impresso, materializado, do DNA, é emissor de ordens para o movimento da vida, o que caracteriza o movimento social é a quantidade de níveis de movimentos presentes em suas linguagens, escrita, oral, ideográfica (VALERY, 1998), contendo ideologias, simbologias, e o próprio conhecimento filosófico e científico. As linguagens são empregadas para o progresso tecnológico e o homem se aproxima de um momento de decolagem do planeta para outros planetas.

O mundo real se apresenta, pois, como um pacote de enorme espessura composto do engavetamento de níveis de movimentos e de objetos. Como se engavetam as matrioshkas, as bonecas russas, menores dentro de maiores. O pacote de mil platôs de DDELEUZE e GUATTARI (1995).

Registre-se que já em 1952, muito antes do aparecimento da teoria do big bang, Jean Gottmann criava a imagem de objetos e de seus movimentos em confronto. O seu modelo teórico compreendia sistemas de movimento e sistemas de resistência ao movimento (que na verdade também é um movimento) No seu caso, ele enfocava a questão de um dado sistema de símbolos, uma iconografia, poder atuar como uma força que interfere impedindo a movimentação livre de um determinado sistema econômico. O nacionalismo, por exemplo, atuando como obstáculo à livre circulação de mercadorias e idéias importadas do exterior (CASTRO, 2010).

A Arte tem o dom de falar por linguagens de imagens e sons, sem a necessidade de explicitação verbal. Por isso mesmo, como na natureza, suas criações podem acontecer sem a intencionalidade racional do seu autor. A idéia da superposição de movimentos expressa neste artigo é reconhecida num filme recente de Godard, Filme Socialismo, embora esta não pareça ser, aparentemente, uma preocupação do cineasta. O filme trata de um cruzeiro de filósofos pelo Mediterrâneo, quando realizam reflexões sobre a 
história e a filosofia. A câmara inicia captando os movimentos das ondas do mar, depois o movimento do navio sobre o mar, depois os passageiros passeando sobre o tombadilho, o movimento das conversas entre os filósofos, as refeições, o sol se pondo num entardecer, etc. As imagens dos portos percorridos evocam o movimento da história do Mediterrâneo, como Atenas, um berço cultural do Ocidente, Barcelona, o último reduto de resistência ao franquismo espanhol, Odessa, local de massacre de levantes que antecederam o comunismo, cujas cenas foram eternizadas por Eisenstein, e hoje escala do turismo capitalista (GODARD, 2010).

Conclusão. História e Geografia na perspectiva filosófica

Neste mundo de criações de novos objetos e movimentos, também é realçado a permanência dos antigos, agora elevados em posição. Milton Santos, David Harvey, Edward Soja, entre outros são nomes associados à recolocação da Geografia num patamar mais alto, valendo-se da ênfase que o pensamento social crítico vem dando à natureza espacial e temporal do mundo real, material e imaterial.

Foi comentado que a expressão formação econômica e social contem implicitamente a noção do espaço e do tempo, através do significado etimológico da palavra formação. Por isso foi empregada por Caio Prado Júnior, título de Formação do Brasil Colonial.

A expressão materialismo histórico coloca o mundo real refletido no mundo do pensamento, ambos dotados de uma dimensão temporal. No entanto, o mundo real e o mundo do pensamento não existem fora de uma dimensão espacial. Contudo, a dimensão temporal do conhecimento é a dimensão da história humana. Só o homem tem presença e existência, todo o resto, mesmo o que existia antes do aparecimento do homem, só passou a existir através da presença do homem. A história humana permite que ele conceba um outro espaço, que não apenas geográfico. Na antiguidade o espaço geográfico englobava os astros tidos como colocados no céu. A materialidade do espaço provoca diferenças com o tempo. No , espaço é possível ir e vir, em diferentes direções. O tempo não permite retornos, a Física contemporânea descarta a possibilidade da viagem para trás, no tempo. Contudo a história humana pode abandonar certos encaminhamentos e passar a trilhar por novos. 
Considerando estes fatos e o fato do tempo do homem ser designado de histórico, e o espaço do homem ser designado de geográfico, seria justo propor um materialismo histórico e geográfico?

Referencias:

BADIOU. Alain, e ALTHUSSER, Louis, 1979, Materialismo Histórico e Materialismo Dialético, São Paulo, Global Editora e Distribuidora.

BRAUDEL. Fernand, 1996, La Méditerranée, Paris, Flmmarion.

CASTRO, Iná Elis de 2010, Um Modelo Geográfico para Pensar o Espaço e a Política na Geografia Cultural, Conferência de Encerramento, ANPEGE, UFPE, Recife.

DELEUZE, Gilles, e GUATTRI, Felix, 1995, Mil Platôs, Rio de Janeiro, Editora 34.

GODARD, Jean-Luc, 2010, Filme Socialismo, França/Suíça.

HAIDEGGER, Martin, 1993, Ser e Tempo, Petrópolis, Vozes.

HOGBEN, Lancelot, 1939, Les Mathématiques Pour Tous, Paris, Payot.

HAWKING, Stephen, 1988, A brief history of time, New York, Bantam Dell Publishing Group.

JAMESON. Frederic, 1996, Pós-Modernismo, A Lógica Cultural do Capitalismo Tardio, São Paulo, Editora Ática S.A.

LEFÉBVRE, Henri, 1947, Logique Formelle, Logique Dialectique, Paris, Éditios Sociales..

MARX, Karl, 1996, A Ideologia Alemã, São Paulo, Hucitec.

SOJA, Edward W. 1989, Post Modern Geographies. The Reassertion of Space in

Critical Social Theories, London, Verso.

SPINOSA, Baruch, 1979, Ética, Espinosa, Os Pensadores, São Paulo. Editora Victor

Civitas.

THE ECONOMIST, 2010, A Quantum Calculation, The Economist, Vol. 395, nº. 8679, April 24: 81-82.

VALERY, Paul, 1998, Introdução ao Método de Leonardo da Vinci, São Paulo. editora 34.

VALLAUX, Camille, 1929, Lês Sciences Geographiques, Paris, Librairie Félix Alcan. VEDRAL, Vlatko, 2010, Decoding Reality. The Universe as Quantum Information, Oxford University Press.

Enviado para publicação em novembro de 2010.

Aceito para publicação em dezembro de 2010. 
Geo UERJ - Ano 12, no. 21, v. 2, p. xx-xx 2ºmestre de 2010. www.geouerj.uerj.br/ojs ISSN 1981-9021 